\title{
Leaf nutrient concentration standards for lemon verbena (Aloysia citrodora Paláu) obtained from field and pot fertilization experiments
}

\author{
Sandra Afonso, Margarida Arrobas*, Isabel Q. Ferreira, Manuel Ângelo Rodrigues \\ Mountain Research Centre - Polytechnic Institute of Bragança, Campus de Santa Apolónia, 5300-253 Bragança, Portugal
}

\section{A R T I C L E I N F O}

\section{Keywords:}

Plant analysis

Sufficiency ranges

Crop nutrient removal

Critical nutrient concentration

\begin{abstract}
A B S T R A C T
Lemon verbena (Aloysia citrodora Paláu) is a perennial shrub native to South America, used in the food industry to add a lemon flavour to food and drink. The species has also caught the attention of the scientific community due to its potential pharmaceutical value. In spite of the useful work that has been carried out in recent years on the chemical composition and pharmacological properties of lemon verbena, very few agronomic studies have been carried out on this crop. There are no studies reporting the elemental composition of this species, making it impossible to monitor crop nutritional status through plant analysis or to establish accurate fertilizer recommendation programs. This work reports results from field and pot fertilization trials that took place in NE Portugal during 2013-2015 to assess crop response to applied N, P, K or B as fertilizers, to establish sufficiency ranges for important macro and micronutrients and SPAD-readings and to estimate crop nutrient removals in aboveground biomass. To this end, a total of 13 fertilizer experiments were conducted which involved 46 cuts of vegetation. Nitrogen fertilization significantly increased dry matter yield of lemon verbena on almost all the sampling dates of the field and pot experiments. In the conditions of these experiments, $\mathrm{P}$ and $\mathrm{K}$ did not increase dry matter yield of lemon verbena. Crop response to applied B was only found in 2014 on a few sampling dates. The sufficiency ranges set for the macronutrients $\mathrm{N}, \mathrm{P}, \mathrm{K}, \mathrm{Ca}$, and $\mathrm{Mg}$ were respectively 28.0-43.0, 0.9-3.8, 10.0-28.0, 7.5-30.0, and 2.0-8.0 $\mathrm{g} \mathrm{kg}^{-1}$. The sufficiency ranges found for the micronutrients $\mathrm{B}, \mathrm{Cu}, \mathrm{Fe}, \mathrm{Zn}$, and Mn were, respectively, 35-200, 7-22, 60-300, 25-125, 40-250 $\mathrm{g} \mathrm{kg}^{-1}$. Adequate SPAD readings were found within the range 40-45. Aboveground dry biomass removed 31.2, 2.2, 25.3, 16.7, and $4.2 \mathrm{~kg} \mathrm{t}^{-1}$, respectively of $\mathrm{N}, \mathrm{P}, \mathrm{K}, \mathrm{Ca}$ and $\mathrm{Mg}$.
\end{abstract}

\section{Introduction}

Lemon verbena (Aloysia citrodora Paláu) is a perennial shrub, belonging to the Verbenaceae family, native to South America (Di Leo Lira et al., 2013). The leaves of the plant emit a pleasant lemon-scent when crushed, and are used to add a lemon flavour to fish and poultry dishes, salads, jams, puddings and non-alcoholic beverages (Cunha et al., 2007, 2012). Its aromatic properties are also used in perfumes and potpourris to scent homes (Brant et al., 2010). In folk medicine, lemon verbena has been used as an antispasmodic, carminative, diuretic, digestive, and sedative agent (Pereira and Meireles, 2007; Cunha et al., 2012; Di Leo Lira et al., 2013). Due to the increased interest in this species, several studies have been done to assess its chemical composition (Carnat et al., 1999; Hudaib et al., 2013; Parodi et al., 2013). Other research has tried to demonstrate antioxidant properties (Pereira and Meireles, 2007; Carrera-Quintanar et al., 2012), antibacterial activity (Rojas et al., 2010; Parodi et al., 2013), or the pharmacological and neuroprotective profiles (Abuhamdah et al., 2015) of the diverse products of lemon verbena. Recent studies have linked lemon verbena to the alleviation of obesity-related disturbances (Herranz-López et al., 2015), prevention of inflammatory disease associated with multiple sclerosis (Mauriz et al., 2015) and post-exercise recovery (Martinez-Rodriguez et al., 2015).

Despite the interest that the scientific community has devoted to this crop, and the consequent range of published papers on its chemical composition and pharmacological properties, agronomic studies on this crop are still very few. Most published work has only a rudimentary agricultural content, usually lasting a year, and simply to obtain plants for chemical analysis, oil extraction and the determination of chemical oil composition. Some studies are published in national journals and are not always in English. Most of those which can be found in the open literature are summarized below. In Iran, Tabatabaie and Nazari (2007) evaluated the influence of nutrient concentrations and $\mathrm{NaCl}$ salinity on the growth, photosynthesis, and essential oil content of lemon verbena in an experiment carried out in slabs/bags filled with perlite and vermiculite (1:1). In a field trial, Mohammadi et al. (2013) studied the production of biomass and essential oil components of lemon verbena

\footnotetext{
* Corresponding author

E-mail addresses: sandracpafonso@gmail.com (S. Afonso), marrobas@ipb.pt (M. Arrobas), isabelaqferreira@gmail.com (I.Q. Ferreira), angelor@ipb.pt (M.Â. Rodrigues).
} 
subjected to the application of several rates and forms of fertilizers. Also from Iran, Nematian et al. (2014) reported the effect of planting density and sowing date on the essential oil content and composition of lemon verbena. In Brazil, Brant et al. (2010) studied the production of biomass and essential oil content of lemon verbena in response to manure applications in an experiment carried out in a greenhouse. Paulus et al. (2013), from an experiment also carried out in Brazil, reported the content and constituents of the essential oil of lemon verbena grown at different planting densities and under varying harvesting regimes.

At present, there is still not a basic theoretical scientific body of knowledge on this species which can guide the production sector in choosing the best agricultural practices. As far as we know, there are no studies reporting the elemental composition of this species, which does not allow monitoring of plant nutritional status through plant analysis. Hence, commercial growers are unable to make use of plant analysis in the implementation of a fertilizer recommendation program due to the lack of threshold values or sufficiency ranges for plant nutrients. The Plant Analysis Handbook III of Bryson et al. (2014), a compilation of data on sufficiency ranges for more than 2000 plant species, including the major herbaceous, shrub and tree crops, but also ornamental plants and forestry species, has no information on lemon verbena.

In this work results are presented on the individual effect of $\mathrm{N}, \mathrm{P}, \mathrm{K}$ or B on dry matter yield and elemental composition of lemon verbena from field trials and pot experiments that took place from 2013 to 2015 in Bragança, NE Portugal. The main goals of the study were: (i) to ascertain the plant response to the applied N, P, K or B; (ii) to set threshold leaf nutrient concentrations or sufficiency ranges for important macro and micronutrients; (iii) to provide a sufficiency range for SPAD-readings, an N nutritional index that can be obtained in the field by using a portable tool; and (iv) to estimate crop nutrient removals in aboveground biomass, a necessary component of the fertilizer recommendation programs. To do this, a set of experiments were carried out, involving a total of 13 fertilizer trials which involved 46 cuts of vegetation.

\section{Material and methods}

\subsection{Study site}

The study consisted of 13 fertilization experiments conducted in NE Portugal. Four fertilizer experiments, one for each of the nutrients N, P, $\mathrm{K}$ and $\mathrm{B}$ were conducted in the field during the growing seasons of 2013 and 2014. Another field experiment was conducted in 2015 as an $\mathrm{N}$ fertilization trial. Eight pot experiments were spread over three years, 2013 (N fertilization trial), 2014 (three fertilization trials with N, P, or K) and 2015 (four fertilization trials with N, P, K, or B).

The region of Bragança benefits from a Mediterranean type climate with average annual air temperature and precipitation of $12.3^{\circ} \mathrm{C}$ and $758 \mathrm{~mm}$, respectively. Average monthly temperature and precipitation for the normal climate 1971-2000 and the meteorological data for the experimental period are presented in Fig. 1.
Table 1

Selected properties of the soils used in the field trials of 2013-2014 (FTrial 2013-14) and 2015 (FTrial 2015) and in the pot experiments of 2013 (PExp 2013), 2014 (PExp 2014), and 2015 (PExp 2015). Soil samples were taken from the $0-20 \mathrm{~cm}$ soil layer.

\begin{tabular}{|c|c|c|c|c|c|}
\hline Soil properties & $\begin{array}{l}\text { FTrial } \\
2013-14\end{array}$ & $\begin{array}{l}\text { FTrial } \\
2015\end{array}$ & $\begin{array}{l}\text { PExp } \\
2013\end{array}$ & $\begin{array}{l}\text { PExp } \\
2014\end{array}$ & $\begin{array}{l}\text { PExp } \\
2015\end{array}$ \\
\hline Clay (\%) & 10.0 & 26.0 & 10.4 & 16.9 & 22.5 \\
\hline Silt (\%) & 12.2 & 21.9 & 18.9 & 18.2 & 20.1 \\
\hline Sand (\%) & 77.8 & 52.1 & 70.7 & 64.9 & 57.4 \\
\hline Texture (USDA) & Sandy loam & Loam & $\begin{array}{l}\text { Sandy } \\
\text { loam }\end{array}$ & $\begin{array}{l}\text { Sandy } \\
\text { loam }\end{array}$ & $\begin{array}{l}\text { Sandy } \\
\text { loam }\end{array}$ \\
\hline $\mathrm{pH}_{\mathrm{H} 2 \mathrm{O}}$ & 6.3 & 6.3 & 6.5 & 6.0 & 6.3 \\
\hline $\mathrm{pH}_{\mathrm{KCl}}$ & 5.0 & 5.3 & 5.9 & 5.3 & 5.3 \\
\hline Organic $C\left(\mathrm{~g} \mathrm{~kg}^{-1}\right)^{\mathrm{a}}$ & 7.7 & 4.8 & 14.5 & 8.4 & 6.8 \\
\hline $\begin{array}{l}\text { Extractable P } \\
\quad\left(\mathrm{mg} \mathrm{kg}^{-1}\right)^{\mathrm{b}}\end{array}$ & 37.8 & 25.6 & 281.5 & 58.0 & 41.0 \\
\hline $\begin{array}{l}\text { Extractable K } \\
\quad\left(\mathrm{mg} \mathrm{kg}^{-1}\right)^{\mathrm{b}}\end{array}$ & 50.5 & 55.1 & 132.5 & 51.9 & 104.0 \\
\hline \multicolumn{6}{|l|}{ Exchangeable bases $^{c}$} \\
\hline $\mathrm{Ca}\left(\mathrm{cmol}_{\mathrm{c}} \mathrm{kg}^{-1}\right)$ & 7.1 & 11.6 & 7.6 & 13.1 & 12.1 \\
\hline $\mathrm{Mg}\left(\mathrm{cmol}_{\mathrm{c}} \mathrm{kg}^{-1}\right)$ & 3.7 & 3.7 & 2.2 & 3.7 & 4.2 \\
\hline $\mathrm{K}\left(\mathrm{cmol}_{\mathrm{c}} \mathrm{kg}^{-1}\right)$ & 0.2 & 0.2 & 0.3 & 0.2 & 0.4 \\
\hline $\mathrm{Na}\left(\mathrm{cmol}_{\mathrm{c}} \mathrm{kg}^{-1}\right)$ & 0.5 & 0.3 & 0.2 & 0.3 & 0.5 \\
\hline
\end{tabular}

${ }^{\text {a }}$ Walkley-Black.

${ }^{\mathrm{b}}$ Egner-Rhiem.

c Ammonium-acetate, pH 7.

The field trials of 2013-14 were carried out on a private farm which is organically managed. The plantation was installed one year before the trial started. When the experiment began the plants entered in their second growing season. The soil is a Leptosol derived from a bed-rock of schist. The cultivated plot was prepared by the farmer on terraces to reduce the slope and facilitate crop management. The field trial of 2015 was purposefully installed for this study in a Regosol of colluvial origin. The properties of these two soils and of those used in the pot experiments are presented in Table 1.

\subsection{Experimental designs and crop management}

The field trials of 2013-2014 were arranged as completely randomized designs with four $\mathrm{N}\left(0,50,100\right.$ and $\left.150 \mathrm{~kg} \mathrm{ha}^{-1} \mathrm{yr}^{-1}\right)$, three $\mathrm{P}$ $\left(0, \quad 21.8\right.$ and $\left.43.7 \mathrm{~kg} \mathrm{ha}^{-1} \mathrm{yr}^{-1}\right)$, three $\mathrm{K}(0,41.5$ and $\left.83.0 \mathrm{~kg} \mathrm{ha}^{-1} \mathrm{yr}^{-1}\right)$ and three $\mathrm{B}\left(0,1\right.$, and $\left.2 \mathrm{~kg} \mathrm{ha}^{-1} \mathrm{yr}^{-1}\right)$ rates. All plots were replicated three times. Each individual plot consisted of six rows $2.8 \mathrm{~m}$ long. In order that the plots of the experimental design of a given nutrient ( $\mathrm{N}, \mathrm{P}, \mathrm{K}$ or $\mathrm{B}$ ) could also receive the other three nutrients, a basal fertilization plan was prepared. It consisted of 100, 43.7, 83.0 and $2 \mathrm{~kg} \mathrm{ha}^{-1} \mathrm{yr}^{-1}$, respectively of N, P, K and B. To supply the nutrients for the experimental designs and for the basal fertilization plan, only fertilizers authorized for organic farming were used. The fertilizers were supplied as nutrient solutions prepared from liquid PK (0:30:20), $\mathrm{N}(8 \%$ total $\mathrm{N}), \mathrm{P}(3.2 \% \mathrm{P})$ and $\mathrm{K}(24.9 \% \mathrm{~K})$ fertilizers. Boron was supplied as sodium borate $(15 \% \mathrm{~B})$. The preparation of the nutrient
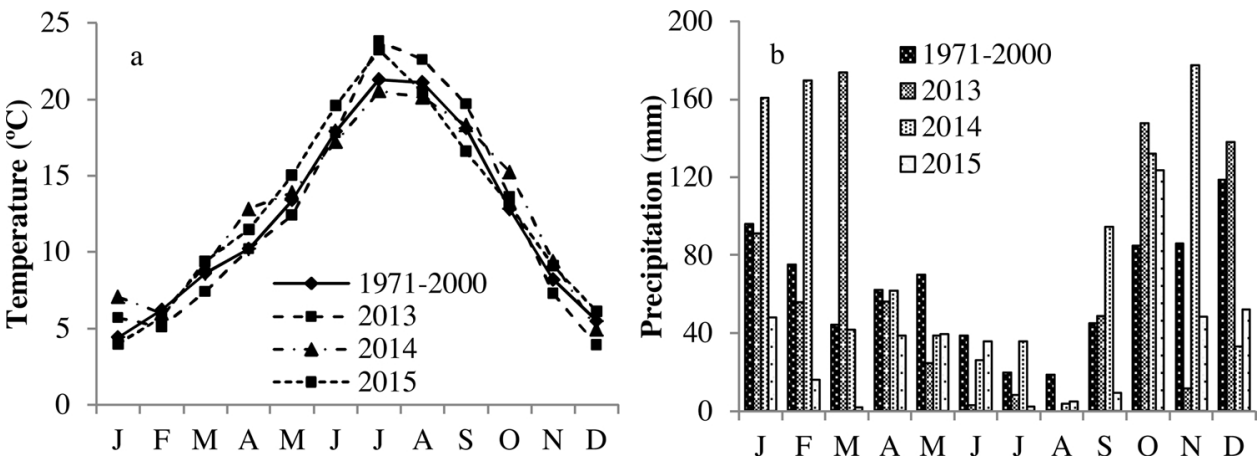

Fig. 1. Mean monthly temperature (a) and accumulated precipitation (b) in 1971-2000 normal climate and during the experimental period (2013-2015). 
solutions took into account the rate of nutrients provided in the experimental design and in the basal fertilization plan, the number of plants per hectare $(50,000)$, the volume of the nutrient solution used per plant $(50 \mathrm{ml})$ and the number of fertilizer applications (four) during the growing season. The fertilization program was split into four applications during the growing season to reduce salinity effects on plants and to increase nutrient use efficiency. The ground was covered by an anti-weed black plastic mat punched with holes spaced at $50 \times 40 \mathrm{~cm}$ where the plants could grow. After being prepared, the nutrient solutions were poured close to the plants into the holes of the mat. The plants were drip-irrigated from May to September.

The field trial of 2015 was also arranged as a completely randomized design with three $\mathrm{N}$ rates $\left(0,200\right.$ and $\left.400 \mathrm{~kg} \mathrm{ha}^{-1}\right)$ and five replications. Ammonium nitrate $(34.5 \% \mathrm{~N})$ was used as a fertilizer. The aim of this apparent excess of $\mathrm{N}$ was to obtain leaf $\mathrm{N}$ concentrations high enough to help to establish the higher limits of the sufficiency range. The fertilizer was split into four equal applications during the growing season, at preplant and as three sidedressings. At preplant, the whole experimental area received also a basal fertilization plan with $43.7 \mathrm{~kg} \mathrm{Pha}^{-1}$ and $83.0 \mathrm{~kg} \mathrm{Kha}^{-1}$, applied, respectively, as superphosphate $\left(18 \% \mathrm{P}_{2} \mathrm{O}_{5}\right)$ and potassium chloride $\left(60 \% \mathrm{~K}_{2} \mathrm{O}\right)$. In this experiment, planting density was 40,000 plants ha ${ }^{-1}(50 \times 50 \mathrm{~cm})$ and the individual plots consisted of seven rows $3 \mathrm{~m}$ long. The field was furrowirrigated from May to September and manually weeded.

The pot experiment of 2013 consisted of an $\mathrm{N}$ fertilization trial where the same fertilizers of the field trials of 2013-14 were used. The experiment was arranged as a completely randomized design with four $\mathrm{N}$ rates $\left(0,0.45,0.90\right.$, and $\left.1.35 \mathrm{~g} \mathrm{pot}^{-1}\right)$ and six replications (six pots). The pots were filled with $4 \mathrm{~kg}$ of dry soil, after being crushed and passed

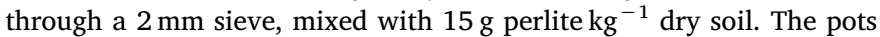
received also $0.39 \mathrm{~g} \mathrm{P} \mathrm{pot}^{-1}, 0.75 \mathrm{~g} \mathrm{~K}$ pot $^{-1}$ and a mixture of secondary macro and micronutrients applied as a fertilizer containing $10 \% \mathrm{MgO}$, $0.3 \% \mathrm{~B}, 18.5 \% \mathrm{SO}_{3}, 0.3 \% \mathrm{Cu}, 2 \% \mathrm{Fe}, 1 \% \mathrm{Mn}, 0.02 \% \mathrm{Mo}$, and $1.6 \% \mathrm{Zn}$ at a rate of $0.08 \mathrm{~g} \mathrm{pot}^{-1}$. The fertilization plan was split into four applications during the growing season. The nutrients were added as a nutrient solution prepared in a similar manner as reported for the field trial of 2013-14. Cuttings of 10-15 cm height were transplanted on 21 March. They were prepared from stems collected in the farm where the field trials were carried out. The pots were thereafter placed in holes in the ground lined with PVC pipe to protect the wall of the pots from direct sunlight and prevent overheating of the rhizosphere, an infrastructure available at the Mountain Research Center of Polytechnic Institute of Bragança. During the growing season the plants were watered as needed to allow normal plant growth.

The pot experiments of 2014 were arranged as a completely randomized design with four $\mathrm{N}\left(0,0.8,1.6\right.$ and $\left.2.4 \mathrm{~g} \mathrm{pot}^{-1}\right)$, three $\mathrm{P}(0$, 0.35 and $\left.0.70 \mathrm{~g} \mathrm{pot}^{-1}\right)$ and three $\mathrm{K}\left(0,0.66\right.$ and $\left.1.33 \mathrm{~g} \mathrm{pot}^{-1}\right)$ rates and eight replications. The experiment of a given nutrient ( $\mathrm{N}, \mathrm{P}$ and $\mathrm{K}$ ) received the other two as a basal fertilization plan, consisting of $1.6 \mathrm{~g} \mathrm{~N}_{\text {pot }}{ }^{-1}, 0.70 \mathrm{~g} \mathrm{P}_{\text {pot }}{ }^{-1}$ and $1.33 \mathrm{~g} \mathrm{~K} \mathrm{pot}^{-1}$. The $\mathrm{N}, \mathrm{P}$ and $\mathrm{K}$ pots also received $0.08 \mathrm{~g}$ of the fertilizer containing a mixture of macro and micronutrients as previously described. The nutrients were supplied as a nutrient solution prepared with the same fertilizers of the previous experiments. The pots were filled with $15 \mathrm{~kg}$ of dry soil, after being crushed and passed through a $2 \mathrm{~mm}$ sieved, mixed with $15 \mathrm{~g}$ perlite $\mathrm{kg}^{-1}$ dry soil. The cuttings were transplanted on 8 May. The nutrient solution was split into four applications during the growing season. The pots were also placed in holes in the ground lined with PVC pipe as reported for the pot experiment of 2013 and watered as needed.

The pot experiments of 2015 were also arranged as completely randomized designs with four rates of $\mathrm{N}\left(0,1.6,3.2\right.$ and $\left.6.4 \mathrm{~g} \mathrm{pot}^{-1}\right), \mathrm{P}$ $\left(0,0.70,1.40\right.$ and $\left.2.79 \mathrm{~g} \mathrm{pot}^{-1}\right)$ and $\mathrm{K}\left(0,1.33,2.66\right.$ and $\left.5.31 \mathrm{~g} \mathrm{pot}^{-1}\right)$, and also four rates of $\mathrm{B}\left(0,32,64\right.$, and $\left.128 \mathrm{mg} \mathrm{pot}^{-1}\right)$, and three replications. The nutrients were supplied as ammonium nitrate $(34.5 \% \mathrm{~N})$, superphosphate $\left(18 \% \quad \mathrm{P}_{2} \mathrm{O}_{5}\right)$, potassium chloride, $\left(60 \% \mathrm{~K}_{2} \mathrm{O}\right)$, and sodium borate $(15 \% \mathrm{~B})$. The high amount of nutrients used in this experiment (estimated as 400,175 and $332 \mathrm{~kg} \mathrm{ha}^{-1}$ of N, P and $\mathrm{K}$, after taking into account a planting density of 62,500 plants $\mathrm{ha}^{-1}$; pot spaced at $40 \times 40 \mathrm{~cm}$ ) aimed to push the leaf nutrient concentrations to values allowing the establishment of higher limits of the sufficiency ranges. The use of conventional fertilizers was due to their higher solubility and availability to plants. A basal fertilization plan was also prepared for the nutrients not included in the experimental designs. It consisted of $2.4,1.0$ and $2.0 \mathrm{~g} \mathrm{pot}^{-1}$ of N, P and $\mathrm{K}$, respectively. A mixture of secondary macro and micronutrients was also added to the $\mathrm{N}, \mathrm{P}$ and $\mathrm{K}$ pots, but not to $\mathrm{B}$ pots, since that fertilizer contains B. The pots were filled with $15 \mathrm{~kg}$ of dry soil mixed with $15 \mathrm{~g}$ perlite $\mathrm{kg}^{-1}$ dry soil. Cuttings of $10-15 \mathrm{~cm}$ were transplanted on 5 May. The nutrients of the experimental design and those of the basal fertilization plan were split in four applications during the growing season. The pots were placed in holes in the ground lined with PVC pipe and watered as needed to allow a normal plant growth.

\subsection{Plant sampling and laboratory analyses}

In the field trials of 2013-14, the plants were sampled three times per year. The dates of sampling were 15 July, 8 August, and 7 October in 2013 and 11 June, 24 July, and 6 October in 2014. At each cut, six plants per plot were randomly selected excluding those of the outer rows. The plants were trimmed $\sim 15 \mathrm{~cm}$ from the soil surface shortly before flowering. A subsample of young mature leaves was used for elemental analysis to serve as the standard tissue for the establishment of the sufficiency ranges. The remaining sample was separated into leaves and stems and used to estimate dry matter yield and plant nutrient recovery. All tissue materials were oven dried at $65^{\circ} \mathrm{C}$, weighed and ground. Tissue analysis was performed by Kjeldahl $(\mathrm{N})$, colorimetry ( $\mathrm{P}$ and $\mathrm{B}$ ), flame emission spectrometry $(\mathrm{K})$, and atomic absorption spectrometry ( $\mathrm{Ca}, \mathrm{Mg}, \mathrm{Cu}, \mathrm{Fe}, \mathrm{Zn}$, and $\mathrm{Mn}$ ) methods.

The plants of the field trial of 2015 were harvested twice (13 August and 31 October) during the growing season. The dates of harvest of the pot experiments were 7 May, 11 June, 12 August, and 4 October 2013, 17 July, 20 August, and 23 October 2014 and 22 June, 5 August, and 27 November 2015. The harvesting procedures and the pre-treatments of tissue samples were the same as reported for the field trial of 2013-2014.

\subsection{SPAD readings}

Estimates of the leaf greenness were recorded by using the portable SPAD-502 Plus chlorophyll meter. The device measures the transmittance of light throughout the leaf in two different wavelengths, $650 \mathrm{~nm}$ (red light, absorbed by chlorophyll pigments) and $940 \mathrm{~nm}$ (infrared light, not absorbed by chlorophyll), displaying chlorophyll-SPAD readings which are proportional to the chlorophyll content of the leaves. The readings were taken from the middle of the blade of fully expanded young leaves. SPAD readings were taken from the field trial of 2013-14 and pot experiments of 2015.

\subsection{Data analysis}

The effect of the fertilizer treatments on dry matter yield of stems, leaves and total was subjected to analysis of variance (ANOVA). When significant differences among treatments occurred, the means were separated by Tukey HSD test ( $\alpha=0.05)$.

Critical nutrient concentration is defined as the point in the curve of the relationship between tissue nutrient concentration and yield below or above which there is, respectively, a high or low probability of obtaining a positive response by the crop if more nutrient is applied (Rodrigues et al., 2005). The concept could also be applied to an excess of a nutrient in a plant tissue to define a critical toxic (or excessive) tissue nutrient concentration. To establish sufficiency ranges, tissue nutrient concentrations were divided into three classes: deficient; 
adequate; and excessive. The boundaries of the adequate range are set by the threshold values as defined above. In this work, when a positive response to a given nutrient is found, critical nutrient concentrations are determined by the graphical method of Cate-Nelson (Cate and Nelson, 1971), modified by declaring the horizontal line at a fixed value (Rodrigues, 2004). From the relationship between leaf nutrient concentration and relative yield, a horizontal line is fixed at $90 \%$ of relative yield, and the vertical line is free to keep the greatest number of points in the positive quadrants. The Cate-Nelson technique has widespread use since it can overcome the difficulty in obtaining a good relationship between tissue nutrient concentration and yield. Relative yields are estimated as the percentage of the maximum yield obtained in individual plots of each experiment. The procedure allows for the removing of most of the experimental variability and comparing critical values from a wide range of conditions. For nutrients for which a response by the crop was not found, or those not included in the experimental design, the sufficiency ranges were estimated by removing $10 \%$ of extreme higher and lower points of the scatterplot, which probably represent outliers associated to experimental error.

Crop nutrient removal was estimated from the higher productive plots of each experiment by multiplying dry matter yield and tissue nutrient concentration after plant samples had been split into leaves and stems and weighed and analyzed separately. The results are expressed per ton of dry biomass.

\section{Results}

\subsection{Crop response to $N, P, K$ and $B$ fertilizers}

Nitrogen fertilization increased dry matter yield of lemon verbena on almost all the sampling dates of the field and pot experiments. The results of the 2014 field trial, for instance, showed a significant increase in leaf and total dry matter yield from 0 to $100 \mathrm{~kg} \mathrm{~N} \mathrm{ha}^{-1}$, followed by stabilization between 100 and $150 \mathrm{~kg} \mathrm{~N} \mathrm{ha}^{-1}$ where dry biomass did not increase (Table 2). In the pot experiment of 2015, a significant increase in dry biomass was found when comparing the control to the treatment corresponding to the highest $\mathrm{N}$ rate $\left(6.4 \mathrm{~g} \mathrm{~N} \mathrm{pot}^{-1}\right)$ (Table 2).

In the conditions of these experiments, $\mathrm{P}$ did not increase dry matter yield of lemon verbena. None of the eleven cuts performed in the field and pot experiments revealed significant differences among fertilizer

Table 2

Leaf and total (leaf + stem) dry matter (DM) yield as a function of growing conditions (field or pot) and nutrient and rate.

\begin{tabular}{|c|c|c|c|}
\hline Growing conditions & Nutrient and rate & Leaf DM yield & Total DM yield \\
\hline \multirow[t]{5}{*}{ Field (2014) } & $\mathrm{N}\left(\mathrm{kg} \mathrm{ha}^{-1}\right)$ & $\left(\text { g plant }^{-1}\right)^{1}$ & $\left(\text { g plant }^{-1}\right)^{1}$ \\
\hline & 0 & $18.0 \mathrm{c}^{\mathrm{A}}$ & $33.9 \mathrm{c}$ \\
\hline & 50 & $29.2 \mathrm{~b}$ & $68.2 \mathrm{~b}$ \\
\hline & 100 & $48.5 \mathrm{a}$ & $103.1 \mathrm{a}$ \\
\hline & 150 & $44.5 \mathrm{a}$ & $105.8 \mathrm{a}$ \\
\hline \multirow[t]{5}{*}{ Pot (2015) } & $\mathrm{N}\left(\mathrm{g} \mathrm{pot}^{-1}\right)$ & $\left(\text { g plant }^{-1}\right)^{2}$ & $\left(\text { g plant }^{-1}\right)^{2}$ \\
\hline & 0 & $9.3 \mathrm{~d}$ & $13.7 \mathrm{~d}$ \\
\hline & 1.6 & $27.5 \mathrm{c}$ & $47.1 \mathrm{c}$ \\
\hline & 3.2 & $40.7 \mathrm{~b}$ & $76.3 \mathrm{~b}$ \\
\hline & 6.4 & $48.3 \mathrm{a}$ & $85.8 \mathrm{a}$ \\
\hline \multirow[t]{4}{*}{ Field (2014) } & B $\left(\mathrm{kg} \mathrm{ha}^{-1}\right)$ & $\left(\text { g plant }^{-1}\right)^{1}$ & $\left(\text { g plant }^{-1}\right)^{1}$ \\
\hline & 0 & $17.8 \mathrm{~b}$ & $48.3 \mathrm{~b}$ \\
\hline & 1 & $20.4 \mathrm{a}$ & $59.3 \mathrm{a}$ \\
\hline & 2 & $20.1 \mathrm{a}$ & $56.4 \mathrm{a}$ \\
\hline \multirow[t]{4}{*}{ Pot (2015) } & $\mathrm{B}\left(\mathrm{mg} \mathrm{pot}^{-1}\right)$ & $\left(\text { g plant }^{-1}\right)^{3}$ & $\left(\text { g plant }^{-1}\right)^{3}$ \\
\hline & 0 & $11.2 \mathrm{a}$ & $18.6 \mathrm{a}$ \\
\hline & 32 & $11.8 \mathrm{a}$ & $19.5 \mathrm{a}$ \\
\hline & 64 & $7.8 \mathrm{~b}$ & $12.7 \mathrm{~b}$ \\
\hline
\end{tabular}

\footnotetext{
${ }^{1,2,3}$ Sum of 3,2 , and 1 cuts of biomass, respectively.

A Within each fertilizer response trial, means followed by the same letter were not significantly different by Tukey HSD test $(\alpha=0.05)$.
}

treatments (data not shown). The use of $\mathrm{K}$ as a fertilizer produced a similar result as reported for P. None of the cuts revealed significant differences among $\mathrm{K}$ fertilizer treatments (data not shown).

Crop response to applied B was only found in 2014 in the field trial. Leaf and total dry matter yields were significantly higher in the fertilized treatments in comparison to the control treatment (Table 2).

In the pot experiment of 2015 , where very high rates of B were used, a significant decrease in dry matter yield was found between the treatments consisting of 32 and $64 \mathrm{mg} \mathrm{B} \mathrm{pot}^{-1}$ (Table 2). The highest rate of $\mathrm{B}\left(128 \mathrm{mg} \mathrm{pot}^{-1}\right)$ completely destroyed the plants, producing no biomass for analysis, and was not included in Table 2. Between the control B treatment and that consisting of $32 \mathrm{mg} \mathrm{B} \mathrm{pot}^{-1}$, dry matter yield was not statistically different.

\subsection{Sufficiency ranges for macro, micronutrients and $S P A D$ readings}

Critical leaf $\mathrm{N}$ concentrations for lemon verbena were established from the relationship between leaf $\mathrm{N}$ concentration and relative dry matter yield by using the Cate-Nelson technique. The procedure was performed for all the seventeen plots for each sampling date of all the field and pot experiments. An example is given in Fig. 2a by using data of the sampling date of 18 August of the pot experiment of 2013. By applying the technique to all plots, values varying between 24 and $33 \mathrm{~g} \mathrm{~kg}^{-1}$ were found. The average of those individual critical leaf $\mathrm{N}$ concentrations is $28 \mathrm{~g} \mathrm{~kg}^{-1}$, this being the value here proposed as the lower limit of the sufficiency range for N. In the pot experiment of 2015 very high rates of $\mathrm{N}$ were used with the aim of establishing critical excessive leaf $\mathrm{N}$ concentrations. These threshold values were set as the average of leaf $\mathrm{N}$ concentrations in the plants grown in the most highly fertilized plots (Fig. 2b). Averaging critical excessive leaf $\mathrm{N}$ concentration obtained from all plots and sampling dates, the result was $43 \mathrm{~g} \mathrm{~kg}^{-1}$, being the value proposed as the higher limit of the sufficiency range for $\mathrm{N}$.

Lemon verbena did not respond to applied $\mathrm{P}$ and $\mathrm{K}$ as fertilizers. In both these situations, the sufficiency ranges were set by removing $\sim 10 \%$ of extreme values, which can be associated to experimental variability. Removing those extreme values, a range remains were there is a high probability to find results of plant analysis from well-nourished plants. The procedure is shown in Fig. 3.

In this study, the response of lemon verbena to applied B was weak. Only on few sampling dates of the field trial of 2014, a significant response of dry matter yield to applied B was found. In these situations, critical leaf $B$ concentrations were established by using the Cate-Nelson technique (Fig. 4a). The lower leaf B concentrations in the plots where a response to applied B was not found, were also used to estimate critical leaf $B$ concentrations. Thus, the lower limit of the sufficiency range for $B$ was the average of the critical leaf $B$ concentrations of the plots where a response of $B$ was observed, and the leaf $B$ concentrations in the control B treatments in the plots where a response of B application was not found. The value estimated was $35 \mathrm{mg} \mathrm{kg}^{-1}$ and is proposed as the lower limit of the sufficiency range for B. In the pot experiment of 2015, where very high rates of $B$ were applied, dry matter yield decreased with the excessive use of B as a fertilizer. Data from this experiment was used to estimate critical excessive leaf B concentrations. These threshold values were found as the average of leaf B concentrations in the plants grown in the most highly fertilized plots from which a decrease in dry matter yield of lemon verbena was not found (Fig. 4b). The average of the threshold values of all these plots was $200 \mathrm{mg} \mathrm{B} \mathrm{kg}^{-1}$, being our proposed value for the upper limit of the sufficiency range for $B$.

To establish sufficiency ranges for the nutrients not included in the experimental design, the methodology reported for the nutrients for which a response by the crop to the applied nutrients was not found, was followed. The methodology consisted of removing $\sim 10 \%$ of extreme values, which are almost certainly outliers associated with experimental error. These instances refer to the macronutrients $\mathrm{Ca}$ and $\mathrm{Mg}$ 


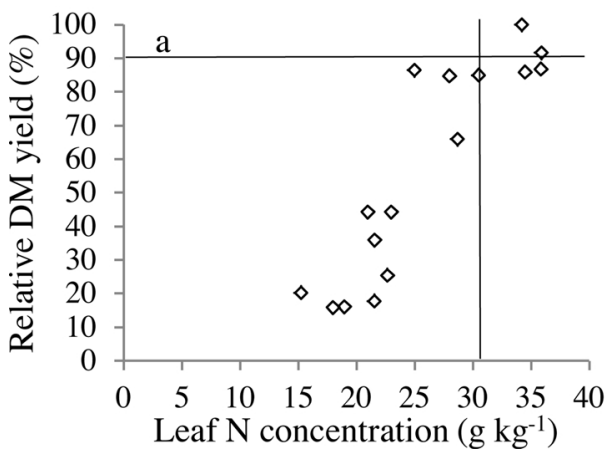

Fig. 2. Critical leaf $\mathrm{N}$ concentration (a) established from the relationship between leaf $\mathrm{N}$ concentration and relative dry matter (DM) yield by using the CateNelson technique (data from the cut of 18 August of the pot experiment of 2013), and critical excessive leaf $\mathrm{N}$ concentration (b) established from the average of leaf $\mathrm{N}$ concentrations in the plants grown in the plots fertilizer with high rates of $\mathrm{N}$ (data from the cut of 22 June of the pot experiment of 2015). and the micronutrients $\mathrm{Cu}, \mathrm{Fe}, \mathrm{Zn}$ and $\mathrm{Mn}$. The results are presented in Fig. 5.

Critical SPAD readings were established for each individual plot based on the relationship between SPAD readings and relative dry matter yield following the Cate-Nelson technique. The scatterplot of the cut of 24 July of the field trial of 2014 is presented in Fig. 6a as an example. The value estimated by averaging all the individual critical SPAD readings was adopted as the lower limit of the sufficiency range for SPAD readings. The value found was 40 units. The average of the SPAD readings recorded in the plants of the most $\mathrm{N}$ fertilized plots was used as the higher limit of the sufficiency range for SPAD readings (Fig. 6b). The value found was 45 units.

Table 3 summarizes the sufficiency ranges established for the macronutrients N, P, K, Ca and Mg, the micronutrients B, Cu, Fe. Zn and $\mathrm{Mn}$ and SPAD readings. The establishment of all these leaf nutrient standards was based on several cuts of biomass performed on plants grown in pots and field conditions.

\subsection{Nutrient removal in aboveground biomass}

Nutrient removal by lemon verbena was estimated from the most productive plots of each experimental design. The aboveground biomass was split into stems and leaves and analyzed separately for elemental composition. Crop nutrient removal was estimated from nutrient concentration and dry matter yield in the different plant parts. The results are expressed per ton of total dry biomass and presented in Table 4.

\section{Discussion}

Applied N significantly increased dry matter yield of lemon verbena in almost all the cuts carried out in the field and pot experiments. It was not possible to find in the literature studies on lemon verbena's response to $\mathrm{N}$ fertilization. However, this kind of result is common in other crops. Soils do not accumulate $\mathrm{N}$ in available forms to plants. In agricultural fields, $\mathrm{N}$ is usually applied as a fertilizer every year to promote crop growth. Alternatively, organic amendments should be added, or the soil/plant system should receive $\mathrm{N}$ through a natural process, such as biological dinitrogen fixation. Previous studies from this region with other crops, such as potato (Solanum tuberosum L.), maize (Zea mays L.), Jerusalem artichoke (Helianthus tuberosus L.), stevia [Stevia rebaudiana (Bertoni)] or olive (Olea europaea L.) have shown significant increases in crop production in response to $\mathrm{N}$ (Rodrigues et al., 2005, 2007, 2011, 2017) or manure (Rodrigues et al., 2006) applications. Green manures and legume cover crops have also promoted the tree nutritional status and enhanced crop production in olive orchards (Rodrigues et al., 2013, 2015). In the study here reported, lemon verbena did not respond to $\mathrm{P}$ and $\mathrm{K}$ fertilization. This does not diminish the importance of these two nutrients in the agricultural systems as is widely recognized (Hawkesford et al., 2012; Havlin et al., 2014). Instead, these soils were probably able to supply enough $\mathrm{P}$ and $\mathrm{K}$ for plant growth from their own means. The crop responded to applied B in the field trial of 2014 but not in the other experiments, and excessive use of B decreased dry matter yield. Boron deficiency is an important nutritional disorder in the agricultural soils of the region. Boron deficiency symptoms and crop response to applied $\mathrm{B}$ are common, mainly in rainfed managed dicots, such as olive (Arrobas et al., 2010) and chestnut (Portela and Louzada, 2012). In this particular study, the response to B application probably was masked by irrigation, since $B$ is water soluble and irrigation can provide appreciable amounts of B (Gupta, 1993). Boron is an essential element, meaning that it is absolutely necessary to plant metabolism, but in excess it can be toxic to plants (Nable et al., 1997; Broadley et al., 2012). In this experiment, high rates of B were used to push the leaf $B$ concentrations to toxic levels to allow the establishment of the higher limit of the sufficiency range. In practice, a toxicity of B is not likely to occur in this region in lemon verbena or other crops. Brant et al. (2010) reported an increase in dry matter yield of lemon verbena with increased rates of cow manure from 0 to $12 \mathrm{~kg} \mathrm{~m}^{-2}$. The result was probably due to a combination of the direct effect of manure on plant growth by releasing nutrients and/or to an indirect effect through the enhancement of general soil growing conditions.
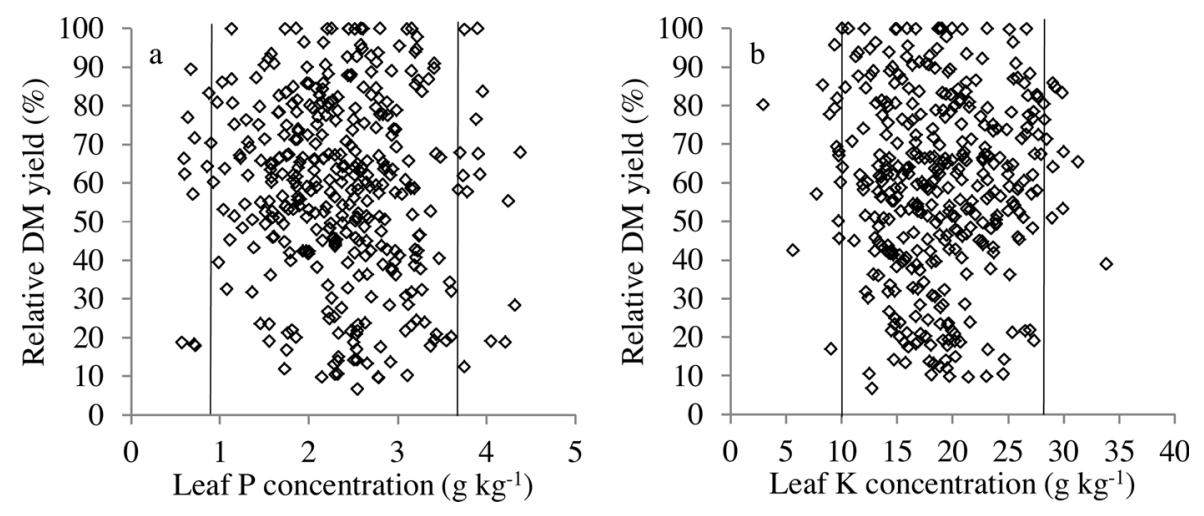

Fig. 3. Sufficiency range for (a) leaf $P$ and (b) K estimated from the relationship between leaf $\mathrm{P}$ or $\mathrm{K}$ concentrations and relative dry matter (DM) yield by removing $\sim 10 \%$ of extreme lower and higher values. 

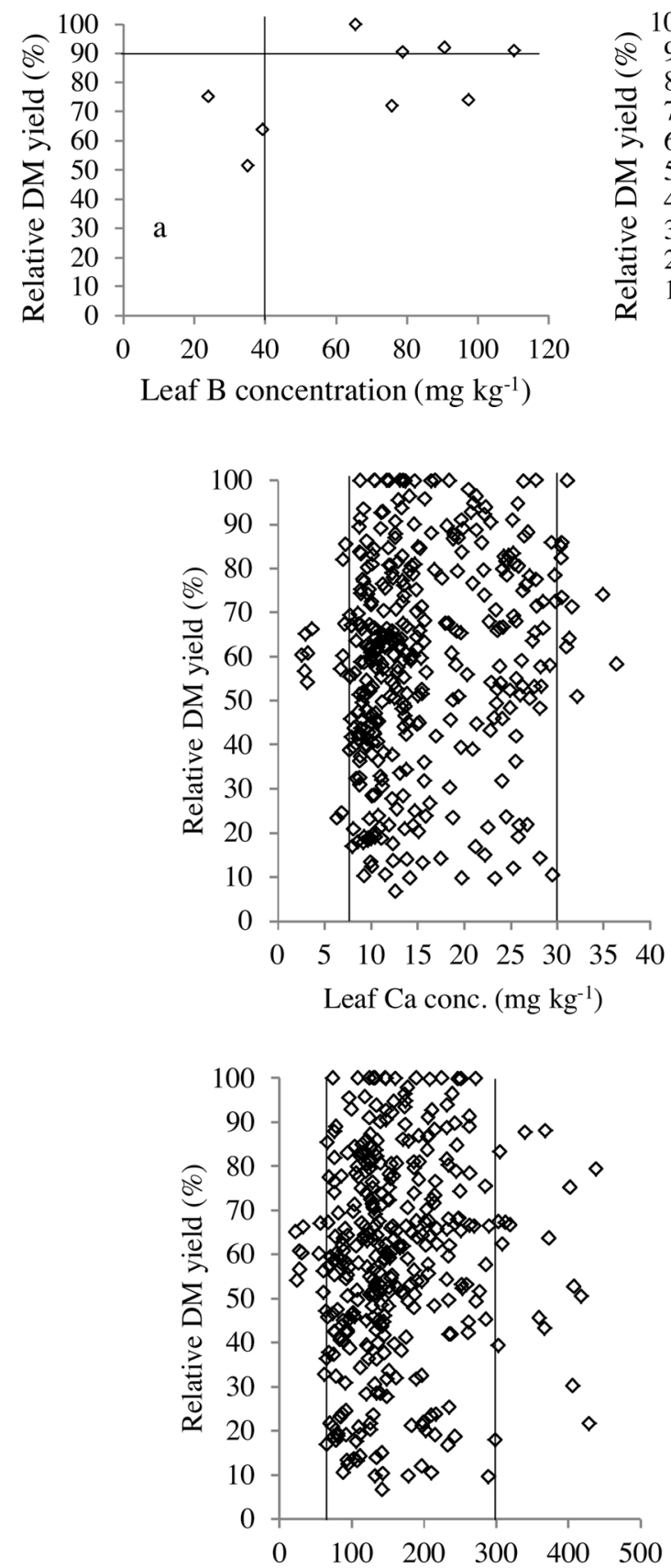

Leaf Fe conc. $\left(\mathrm{mg} \mathrm{kg}^{-1}\right)$

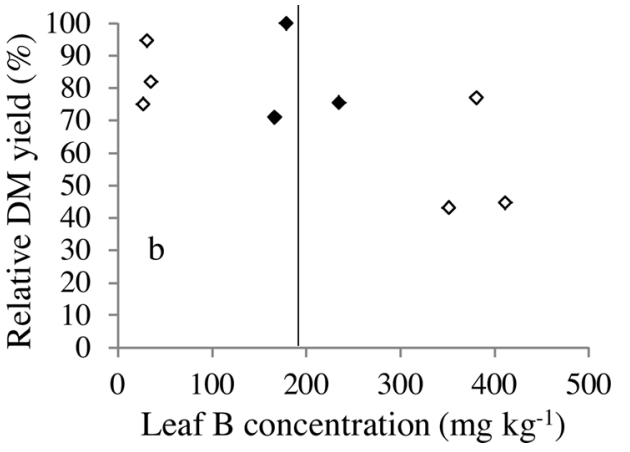

Fig. 4. Critical leaf $B$ concentration (a) established from the relationship between leaf B concentration and relative dry matter (DM) yield by using the CateNelson technique (data from the cut of 24 July of the field trial of 2014) and critical excessive leaf B concentration (b) established from the average of leaf B concentrations in the plants grown in the plots fertilizer with high rates of $\mathrm{B}$ (data from the sampling date of 22 June of the pot experiment of 2015).
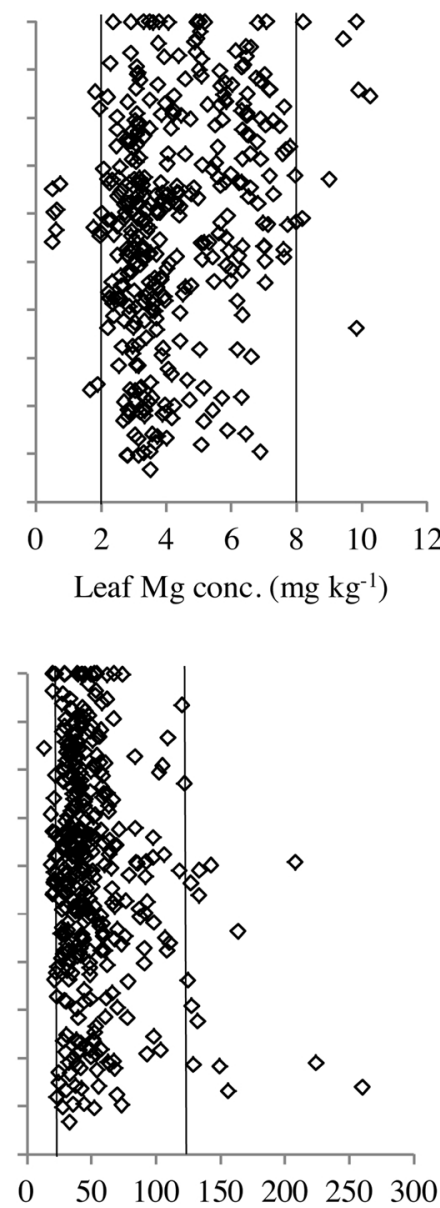

Leaf $\mathrm{Zn}$ conc. $\left(\mathrm{mg} \mathrm{kg}^{-1}\right)$
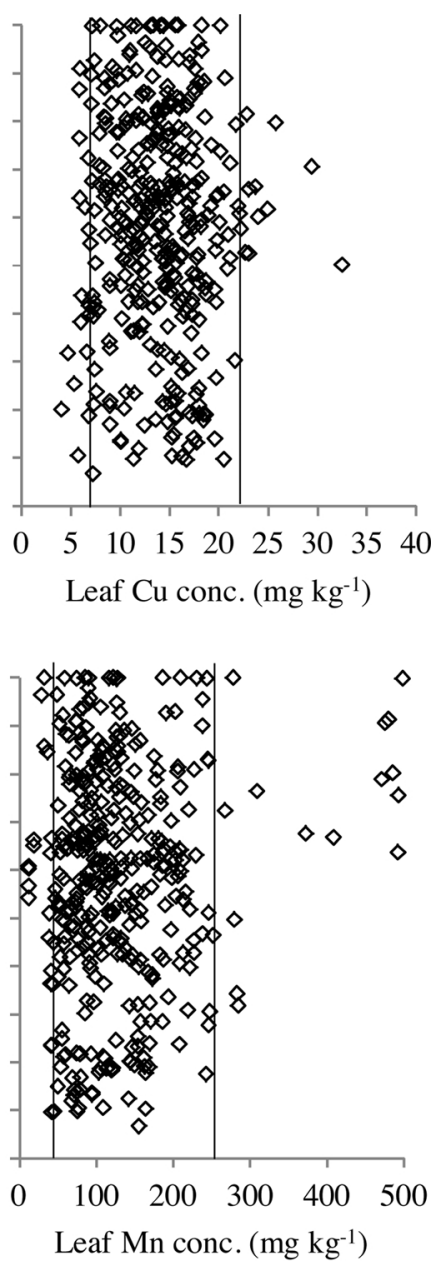

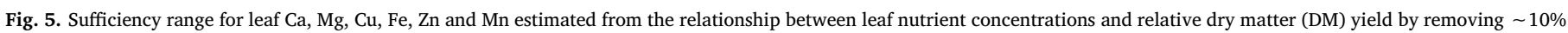
of extreme lower and higher values.

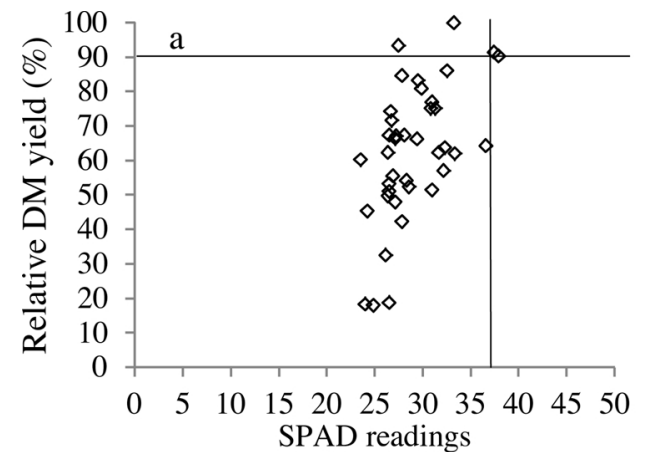

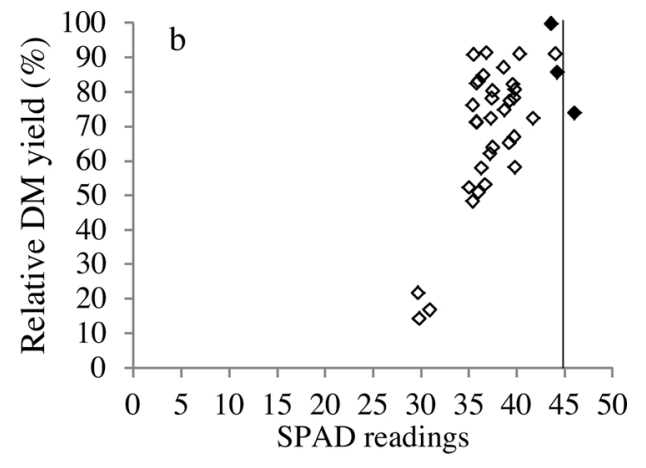

Fig. 6. Critical SPAD readings (a) established from the relationship between SPAD readings and relative dry matter (DM) yields by using the Cate-Nelson technique (data from the cut of 24 July of the field trial of 2014) and critical excessive SPAD readings (b) established from the average of SPAD readings recorded in the plants grown in the plots fertilizer with the highest rates of $\mathrm{N}$ (data from the cut of 22 June of the pot experiment of 2015). 
Table 3

Sufficiency ranges for macronutrients, micronutrients and SPAD-readings.

\begin{tabular}{|c|c|c|c|}
\hline \multicolumn{2}{|c|}{ Macronutrients $\left(\mathrm{g} \mathrm{kg}^{-1}\right)$} & \multicolumn{2}{|c|}{ Micronutrients $\left(\mathrm{g} \mathrm{kg}^{-1}\right)$} \\
\hline Nitrogen & $28.0-43.0$ & Boron & $35-200$ \\
\hline Phosphorus & $0.9-3.8$ & Copper & $7-22$ \\
\hline Potassium & $10.0-28.0$ & Iron & $60-300$ \\
\hline Calcium & $7.5-30.0$ & Zinc & $25-125$ \\
\hline \multirow[t]{2}{*}{ Magnesium } & $2.0-8.0$ & Manganese & $40-250$ \\
\hline & SPAD-readings & $40-45$ & \\
\hline
\end{tabular}

\section{Table 4}

Nutrient removal (average \pm standard error) in the aboveground biomass of lemon verbena estimated from the dry matter yield of each plat part and respective elemental composition and expressed per ton of total dry biomass.

\begin{tabular}{|c|c|c|c|}
\hline & \multicolumn{3}{|c|}{ Nutrient removal } \\
\hline & Leaves & Stems & $\begin{array}{l}\text { Total } \\
\text { (leaves + stems) }\end{array}$ \\
\hline Nitrogen $\left(\mathrm{kg} \mathrm{t}^{-1} \mathrm{DM}\right)$ & $11.2 \pm 1.71$ & $19.9 \pm 1.72$ & $31.2 \pm 2.62$ \\
\hline $\begin{array}{l}\text { Phosphorus }\left(\mathrm{kg} \mathrm{t}^{-1}\right. \\
\text { DM) }\end{array}$ & $0.5 \pm 0.10$ & $1.6 \pm 0.31$ & $2.2 \pm 0.35$ \\
\hline $\begin{array}{l}\text { Potassium }\left(\mathrm{kg} \mathrm{t}^{-1}\right. \\
\quad \mathrm{DM})\end{array}$ & $7.1 \pm 0.88$ & $18.2 \pm 2.36$ & $25.3 \pm 2.37$ \\
\hline Calcium $\left(\mathrm{kg} \mathrm{t}^{-1} \mathrm{DM}\right)$ & $7.4 \pm 0.83$ & $9.5 \pm 1.47$ & $17.0 \pm 1.59$ \\
\hline $\begin{array}{l}\text { Magnesium } \mathrm{kg} \mathrm{t}^{-1} \\
\text { DM) }\end{array}$ & $1.8 \pm 0.33$ & $2.3 \pm 0.39$ & $4.2 \pm 0.61$ \\
\hline Boron $\left(\mathrm{g} \mathrm{t}^{-1} \mathrm{DM}\right)$ & $33.6 \pm 2.76$ & $11.4 \pm 2.01$ & $45.0 \pm 2.96$ \\
\hline Iron $\left(\mathrm{g} \mathrm{t}^{-1} \mathrm{DM}\right)$ & $60.4 \pm 20.40$ & $100.4 \pm 51.51$ & $160.7 \pm 64.14$ \\
\hline Copper $\left(\mathrm{g} \mathrm{t}^{-1} \mathrm{DM}\right)$ & $4.6 \pm 1.23$ & $10.2 \pm 2.36$ & $14.7 \pm 3.12$ \\
\hline Zinc $\left(\mathrm{gt}^{-1} \mathrm{DM}\right)$ & $13.0 \pm 5.23$ & $22.1 \pm 7.13$ & $35.1 \pm 10.18$ \\
\hline $\begin{array}{l}\text { Manganese } \\
\qquad\left(\mathrm{g} \mathrm{t}^{-1} \mathrm{DM}\right)\end{array}$ & $17.7 \pm 3.79$ & $25.5 \pm 14.58$ & $43.2 \pm 15.97$ \\
\hline
\end{tabular}

Data on leaf nutrient concentrations of lemon verbena are not available in the open literature as far as we know. Thus, the threshold values and the sufficiency ranges for lemon verbena here reported could not be compared to others for the same species. If we try to compare the sufficiency ranges here proposed for lemon verbena to those reported by Bryson et al. (2014) for other important crops which are widely grown in the region, such as potatoes, winter wheat, maize or olive, the values are of the same order of magnitude but with tolerable differences for individual nutrients and species.

Few studies have reported data on dry matter yield of lemon verbena and most of them were carried out in greenhouses with potted plants (Tabatabaie and Nazari, 2007; Brant et al., 2010). A field experiment was carried out in Brazil with the aim of studying the content and constituents of essential oil of lemon verbena at different planting densities and under different harvesting regimes (Paulus et al., 2013). Thus, there is no consolidated data on dry matter yield and leaf nutrient concentration for this species as has already been mentioned. To estimate crop nutrient removal, which is an important component of fertilizer recommendation systems, since it is a measure of crop needs, we used the most productive plots, which combine high dry matter yields and leaf nutrient concentrations within the sufficiency ranges. The results were expressed per ton of dry biomass (leaves + stems). Using this approach, nutrient removal can now be easily estimated in any part of the world from local yield goals.

\section{Conclusions}

Lemon verbena showed a strong response to $\mathrm{N}$ applied as a fertilizer in the conditions of these experiments, which means that particular attention should be given to this element in crop management. In contrast, there was no significant response to applied $\mathrm{P}$ and $\mathrm{K}$ as fertilizers. Crop response to applied B was only found in the field trial of 2014. Sufficiency ranges for 10 essential nutrients were made available, which will allow the diagnosis of the nutritional status of lemon verbena by means of plant analysis through the comparison of actual leaf nutrient concentrations with the sufficiency ranges here reported. Data on crop removal for 10 important macro and micronutrients were also provided, which can help to establish a fertilizer recommendation program for this crop, since crop nutrient removal provides a direct indication of crop needs.

\section{Acknowledgements}

The authors are grateful to the Foundation for Science and Technology (FCT, Portugal) and FEDER under Programme PT2020 for financial support to CIMO (UID/AGR/00690/2013) and also to the project "Sustainable management of medicinal and aromatic plants" (PRODER 46025).

\section{References}

Abuhamdah, S., Abuhamdah, R., Howes, M.-J.R., Al-Olimat, S., Ennaceur, A., Chazot, P.L., 2015. Pharmacological and neuroprotective profile of an essential oil derived from leaves of Aloysia citrodora Palau. Journal of Pharmacy and Pharmacology 67, 1306-1315.

Arrobas, M., Lopes, J.I., Pavão, F., Cabanas, J.E., Rodrigues, M.A., 2010. Comparative boron nutritional diagnosis for olive based on July and January leaf samplings. Communications in Soil Science and Plant Analysis 41, 709-720.

Brant, R.S., Pinto, J.E.B.P., Bertolucci, S.K.V., Albuquerque, C.J.B., 2010. Produção de biomassa e teor do óleo essencial de cidrão em função da adubação orgânica. Horticultura Brasileira 28, 111-114.

Broadley, M., Brown, P., Cakmak, I., Rengel, Z., Zhao, F., 2012. Function of nutrients, micronutrients. In: Marschner, P. (Ed.), Marschner's Mineral Nutrition of Higher Plants. Elsevier, London, UK, pp. 191-248.

Bryson, G., Mills, H.A., Sasseville, D.N., Jones Jr., J.B., Barker, A.V., 2014. Plant Analysis Handobook III. A Guide to Sampling, Preparation, Analysis and Interpretation for Agronomic and Horticultural Crops. Micro-Macro Publishing, Inc., Athens, GA.

Carnat, A., Carnat, A.P., Fraisse, D., Lamaison, J.L., 1999. The aromatic and polyphenolic composition of lemon verbena tea. Fitoterapia 70, 44-49.

Carrera-Quintanar, L., Funes, L., Viudes, E., Tur, J., Micol, V., Roche, E., Pons, A., 2012. Antioxidant effect of lemon verbena extracts in lymphocytes of university students performing aerobic training program. Scandinavian Journal of Medicine \& Science in Sports 22 (4), 454-461.

Cate Jr., R.B., Nelson, L.A., 1971. A simple statistical procedure for portioning soil test correlation data into two classes. Soil Science Society of America Proceedings 35, 658-660.

Cunha, A.P., Ribeiro, J.A., Roque, O.R., 2007. Plantas aromáticas em Portugal. Caracterização e utilização. Fundação Calouste Gulbenkian, Lisboa.

Cunha, A.P., Nogueira, M.T., Roque, O.R., 2012. Plantas aromáticas e óleos essenciais, composição e aplicações. Fundação Calouste Gulbenkian, Lisboa.

Di Leo Lira, P., Van Baren, C.M., López, S., Molina, A., Heit, C., Viturro, C., De Lampasona, M.P., Catalán, C.A., Bandoni, A., 2013. Northwestern Argentina, a center of genetic diversity of lemon verbena (Aloysia citrodora Palau), Verbenaceae. Chemistry \& Biodiversity 10 (2), 251-261.

Gupta, U.C., 1993. Sources of boron. In: Gupta, U.C. (Ed.), Boron and Its Role in Crop Production. CRC Press, Boca Raton, Florida, pp. 45-51.

Havlin, J.L., Tisdale, S.L., Nelson, W.L., Beaton, J.D., 2014. Soil Fertility and Fertilizers, an Introduction to Nutrient Management, 8th edition. Pearson, Inc, New Jersey, USA.

Hawkesford, M., Horst, W., Kichey, T., Lambers, H., Schjoerring, J., Moller, I.S., White, P., 2012. Function of macronutrients. In: Marschner, P. (Ed.), Marschner's Mineral Nutrition of Higher Plants. Elsevier, London, UK, pp. 135-189.

Herranz-López, M., Barrajón-Catalán, E., Segura-Carretero, A., Menéndez, J.A., Joven, J., Micol, V., 2015. Lemon verbena (Lippia citriodora) polyphenols alleviate obesity-related disturbances in hypertrophic adipocytes through AMPK-dependent mechanisms. Phytomedicine 22, 605-614.

Hudaib, M., Tawaha, K., Bustanji, Y., 2013. Chemical profile of the volatile oil of lemon verbena (Aloysia citriodora Paláu) Growing in Jordan. Journal of Essential Oil Bearing Plants 16, 568-574.

Martinez-Rodriguez, A., Moya, M., Vicente-Salar, N., Brouzet, T., Carrera-Quintanar, L., Cervello, E., Micol, V., Roche, E., 2015. Biochemical and psychological changes in university students performing aerobic exercise and consuming lemon verbena extracts. Current Topics in Nutraceutical Research 13 (2), 95-102.

Mauriz, E., Vallejo, D., Tunon, M., Rodriguez-Lopez, J., Rodriguez-Perez, R., Sanz-Gomez, J., Garcia-Fernandez, M.D., 2015. Effects of dietary supplementation with lemon verbena extracts on serum inflammatory markers of multiple sclerosis patients. Nutrición Hospitalaria 31 (2), 764-771.

Mohammadi, M., Tobeh, A., Vahidipour, H.R., Fakhari, R., 2013. Effects of biological fertilizers on essential oil components and quantitative and qualitative yield of lemon verbena (Lippia citriodora). International Journal of Agriculture and Crop Sciences 5, 1374-1380.

Nable, R.O., Bañuelos, G.S., Paull, J.G., 1997. Boron toxicity. Plant Soil 198, 181-198.

Nematian, A., Dalvandi, G.R., Shariati, M.A., 2014. Effect of planting density and sowing date on the essential oil content and composition of lemon balm (Lippia citriodora). 
International Journal of Biosciences 5, 56-63.

Parodi, T.V., Vargas, A.P.C., Krewer, C., Flores É, M.M., Baldisserotto, B., Heinzmann, B.M., Oliveira, J.V., Popiolski, A.S., Minozzo, M., 2013. Chemical composition and antibacterial activity of Aloysia triphylla (L'HÉrit) Britton extracts obtained by pressurized $\mathrm{CO}_{2}$ extraction. Brazilian Archives of Biology and Technology 56, 283-292.

Paulus, D., Valmorbida, R., Toffoli, E., Nava, G.A., Paulus, E., 2013. Teor e composição química do óleo essencial e crescimento vegetativo de Aloysia triphylla em diferentes espaçamentos e épocas de colheita. Revista Ceres (Viçosa) 60, 372-379.

Pereira, C.G., Meireles, M.A.A., 2007. Evaluation of global yield, composition, antioxidant activity and cost of manufacturing of extracts from lemon verbena (Aloysia triphylla [l'hérit.] britton) and mango (Mangifera indica L.) leaves. Journal of Food Process Engineering 30, 150-173.

Portela, E.M., Louzada, J.L., 2012. Early diagnosis of boron deficiency in chestnut. Journal of Plant Nutrition 35, 304-310.

Rodrigues, M.A., Coutinho, J., Martins, J., Arrobas, M., 2005. Quantitative sidedress nitrogen recommendations for potatoes based upon crop nutritional indices. European Jounal of Agronomy 23, 79-88.

Rodrigues, M.A., Pereira, A., Cabanas, J.E., Dias, L., Pires, J., Arrobas, M., 2006. Crops use-efficiency of nitrogen from manures permitted in organic farming. European Journal of Agronomy 25, 328-335.

Rodrigues, M.A., Sousa, L., Cabanas, J.E., Arrobas, M., 2007. Tuber yield and leaf mineral composition of Jerusalem artichoke (Helianthus tuberosus L.) grown under different cropping practices. Spanish Journal of Agricultural Research 5 (4), 545-553.

Rodrigues, M.A., Pavão, F., Lopes, J.I., Gomes, V., Arrobas, M., Moutinho-Pereira, J., Ruivo, S., Cabanas, J.E., Correia, C.M., 2011. Olive yields and tree nutritional status during a four year period without nitrogen and boron fertilization. Communications in Soil Science and Plant Analysis 42 (7), 803-814.

Rodrigues, M.A., Correia, C.M., Claro, A.M., Ferreira, I.Q., Barbosa, J.C., MoutinhoPereira, J.M., Bacelar, E.A., Fernandes-Silva, A.A., Arrobas, M., 2013. Soil nitrogen availability in olive orchards after mulching legume cover crop residues. Scientia

Horticulturae 156, 45-51. http://dx.doi.org/10.1016/j.scienta.2013.04.035.

Rodrigues, M.A., Dimande, P., Pereira, E., Ferreira, I.Q., Freitas, S., Correia, C.M., Moutinho-Pereira, J., Arrobas, M., 2015. Early-maturing annual legumes, an option for cover cropping in rainfed olive orchards. Nutrient Cycling in Agroecosystems 103, 153-166. http://dx.doi.org/10.1007/s10705-015-9730-5.

Rodrigues, M.A., Afonso, S., Ferreira, I.Q., Arrobas, M., 2017. Response of stevia to nitrogen fertilization and harvesting regime in Northeastern Portugal. Archives of Agronomy and Soil Science 63 (5), 626-637. http://dx.doi.org/10.1080/03650340. 2016.1230272 .

Rodrigues, M.A., 2004. Establishment of continuous critical levels for indices of plant and pre-sidedress soil N status in the potato crop. Communications in Soil Science and Plant Analysis 35, 2067-2085.

Rojas, L.B., Velasco, J., Diaz, T., Otaiza, R.G., Carmona, J., Usubillaga, A., 2010. Chemical composition and antibacterial effects of the essential oil of Aloysia triphylla against genitourinary pathogens. Boletín Latinoamericano y del Caribe de Plantas Medicinals y Aromáticas 9, 56-62.

Tabatabaie, S.J., Nazari, J., 2007. Influence of nutrient concentrations and $\mathrm{NaCl}$ salinity on the growth, photosynthesis, and essential oil content of peppermint and lemon verbena. Turkish Journal of Agriculture and Forestry 31, 245-253. 